JURNAL KESEHATAN PENA MEDIKA VOL 10 (2) DES 2020

PENA MEDIKA

FAKULTAS ILMU KESEHATAN UNIVERSITAS PEKALONGAN

http://jurnal.unikal.ac.id/index.php/medika ISSN : 2086-843X

\title{
Hubungan Antara Faktor Sosiodemografi, Sosioekonomi Dan Sosiobudaya Dengan Pencarian Pengobatan Malaria Di Puskesmas Kaligesing Kabupaten Purworejo
}

\author{
I Made Setya Adi Purnama ${ }^{1}$ \\ ${ }^{1}$ Dosen Program Studi Keperawatan Akademi Kesehatan Asih Husada Semarang

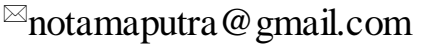

\begin{abstract}
ARTICLE INFO :
Accepted : 2020-12-01

Approve : 2020-12-22

Publish : 2020-12-27
\end{abstract}

\begin{abstract}
Malaria cases are widely found in Indonesia with 30.000 of death every year. Purworejo is one of endemic area of malaria in Indonesia. There is increasing of malaria cses every year in Purworejo. Furthermore, people in Purworejo assume that malaria is so common disease. The research was observational-analitic research with cross sectional design. Number of sample were 70 people. Sample of research consisted of two group, which are malaria patient who got medical treatment and malaria patient who got traditional treatment. Analysis of relationship between independence and dependence variable was tested by Chi-Square test. Meanwhile analysis of most influential variable applied logistic regression. There were four variables related with malaria seeking care, gender, belief, knowledge and perception of seriousness. Variable that simultaneously affected malaria seeking care were knowledge and perception of seriousness. Meanwhile the most influential variable was perception of seriousness.
\end{abstract}

Keyword : Health Seeking Behavior, Malaria

\begin{abstract}
ABSTRAK
Malaria ditemukan tersebar luas di Indonesia dengan jumlah 30.000 kematian setiap tahun. Purworejo adalah salah satu daerah endemis malaria di Indonesia. Terjadi peningkatan jumlah kasus malaria setiap tahun di Purworejo. Selain itu, masyarakat Purworejo menganggap malaria adalah penyakit yang sudah biasa terjadi. Penelitian ini merupakan penelitian observasional analitik dengan desain penelitian cross sectional. Sampel penelitian berjumlah 70 orang. Sampel penelitian terdiri dari dua kelompok, yaitu penderita malaria yang memilih pengobatan medis dan pengobatan tradisional. Analisis hubungan antara variabel bebas dan terikat diuji dengan uji Chi-Square dan Regresi logistik.Hasil penelitian ini menunjukkan bahwa terdapat empat variabel yang berhubungan dengan pencarian pengobatan malaria, yaitu jenis kelamin, kepercayaan, pengetahuan dan keparahan yang dirasakan. variabel yang secara bersama-sama berpengaruh terhadap pencarian pengobatan malaria adalah pengetahuan dan keparahan
\end{abstract}


yang dirasakan. Sedangkan variabel yang paling berpengaruh terhadapa pencarian pengobatan malaria adalah keparahan yang dirasakan responden penelitian.

Kata Kunci : Perilaku Pencarian Pengobatan, Malaria

\section{PENDAHULUAN}

Malaria adalah salah satu isu kesehatan masyarakat yang saat ini masih banyak terjadi di seluruh dunia. Berdasarkan data dari WHO (2017), terdapat 109 negara endemik malaria dan 31 diantaranya tercatat sebagai negara dengan jumlah korban tinggi akibat malaria (malaria-high burden countries). WHO juga memperkirakan bahwa terdapat sekitar 250 juta kasus malaria dengan 1 juta kematian setiap tahun. Hal ini penting mengingat 3,3 milyar sampai setengah penduduk dunia hidup di daerah yang berisiko terhadap malaria. Untuk mengatasi masalah tersebut, dalam pertemuan WHA (World Health Assembly) ke 60 tanggal 18 Mei 2007, telah dihasilkan komitmen global eliminasi malaria bagi setiap Negara yang dirumuskan oleh WHO, yaitu Global Malaria Program. Indonesia merupakan salah satu negara di dunia dimana malaria masih menjadi isu kesehatan masyarakat yang menonjol. Data WHO tahun 2010 menunjukan, Indonesia menyumbang sekitar 224 ribu dari 24 juta kasus malaria di dunia. Jumlah malaria pada tahun 2012 mencapai 417 ribu kasus di Indonesia. Wilayah Indonesia Timur merupakan salah satu daerah dengan tingkat kejadian malaria tertinggi. Hampir tiga per empat dari 417 ribu kasus tersebut berasal dari wilayah Indonesia bagian timur seperti Papua, dan Nusa Tenggara Timur. Papua memiliki angka kasus malaria terbesar yaitu 42.65 persen kasus di Indonesia (Kementerian Kesehatan RI, 2013).

Salah satu faktor penting dalam penanggulangan kasus malaria adalah pencarian pengobatan malaria. Perilaku pencarian pengobatan/pemyembuhan adalah perilaku orang atau masyarakat yang sedang mengalami sakit atau masalah kesehatan yang lain, untuk memperoleh pengobatan sehingga sembuh dari masalah kesehatannya (Ajami, 2016). Pencarian pengobatan malaria menjadi penting terkait fakta bahwa masih banyak masyarakat yang memilih teknik pengobatan tradisional, seperti minum jamu atau dukun. Padahal jenis pengobatan tradisional belum teruji secara ilmiah untuk bisa 
mengobati secara menyeluruh dan mencegah terjadinya relaps. Hal ini penting mengingat terdapat layanan kesehatan di daerah yang diharapkan membantu pengoabatn malaria pada masyarakat (Ipa, 2015).

Kabupaten Purworejo adalah salah satu daerah di Jawa Tengah yang merupakan daerah endemik malaria. Pada tahun 2012 terjadi 547 kasus dengan API sebesar 0,57\%, akan tetapi meningkat pada tahun 2013 sebesar 728 kasus dengan API sebesar 0,98\% yang telah mencapai target di bawah 1\%. Pada tahun 2014 meningkat menjadi 803 kasus dengan API 1,13\%. Sedangkan pada tahun 2015 terdapat 214 kasusbaru malaria. Berdasarkan uraian di atas, maka perlu dilakukan penelitian yang menganalisis hubungan faktor sosiodemografi, sosioekonomi dan sosiobudaya dengan pencarian pengobatan malaria di Puskesmas Kaligesing Kabupaten Purworejo.

\section{METODE PENELITIAN}

Penelitian ini adalah penelitian analitik dengan desain cross sectional. Populasi dalam penelitian ini adalah adalah penderita malaria di Kecamatan Kaligesing Kabupaten Purworejo yang melakukan pengobatan malaria tahun 2016 yqng bersifat infinit. Pengambilan sampel penelitian menggunakan teknik simple random sampling yang total membutuhkan 70 orang. Penelitian ini dilakukan mulai bulan Agustus 2016 sampai Desember 2017 di Kecamatan Kaligesing Kabupaten Purworejo. Hasil penelitian ini dianalisis mengunakan dua uji statistik. Uji Chi-Square dipilih untuk menganalisis hubungan antara vaiabel bebas dan terikat. Sedangkan regresi logistik ganda digunakan untuk mengetahui pengaruh secara bersama variabel bebas pada variabel terikat.

\section{HASIL DAN PEMBAHASAN}

Umur

Hasil penelitian menunjukkan bahwa sebagian besar responden yang mencari pengobatan tradisional berada pada kelompok umur dewasa yang berjumlah 11 orang $(39,2 \%)$. Sedangkan sebagian besar responden yang mencari pengobatan medis juga berada pada kelompok umur dewasa yang berjumlah 24 orang $(50,0 \%)$. Hasil analisis dengan uji Chi-Square menghasilkan $p$-value $=0,300$ yang berarti tidak ada perbedaan hubungan antara umur responden penelitian 
dengan perilaku pencarian pengobatan malaria baik secara medis maupun tradisional.

Umur merupakan lama hidup yang dihitung sejak dilahirkan. Semakin bertambah umur sesorang, semakin banyak pula daya tanggapnya. Melalui perjalanan umurnya, semakin dewasa individu yang bersangkutan akan melakukan adaptasi perilaku terhadap lingkungan. Umur adalah faktor sosiodemografi yang mempengaruhi pengetahuan seseorang yang merupakan faktor penguat (reinforcing factor). Secara teori, umur seseorang berbanding lurus dengan pengetahuan yang akan dimiliki (Nizar, 2013). Pengetahuan kemudian menjadi dasar pembentukan perilaku seseorang. Oleh karena itu, semakin tua umur seseorang maka semakin besar pula kemungkinan dia berperilaku baik, termasuk perilaku kesehatan yaitu pencarian pengobatan malaria.

Hasil penelitian ini sesuai dengan peneltitian Nizar dkk (2013) yang menyebutkan tidak ada hubungan umur pencarian pengobatan malaria. Perilaku kesehatan seseorang tidak hanya berhubungan dengan umur, tetapi juga berbagai variabel lain. Hal ini penting mengingat responden penelitian ini berdomisili di daerah endemik malaria. Perilaku kesehatan mereka tidak dipengaruhi dan dibentuk oleh pengetahuan, namun cenderung dibentuk oleh aspek kepercayaan yang dimiliki sejak lama karena diturunkan secara cultural dalam keluarga. Padahal kepercayaan tentang pengobatan belum tentu benar dan bisa dipercaya efektivitasnya secara ilmiah.

\section{Jenis Kelamin}

Hasil penelitian menunjukkan bahwa sebagian besar responden yang mencari pengobatan tradisional adalah responden laki-laki yang berjumlah 17 orang $(60,7 \%)$. Sedangkan sebagian besar responden pengobatan medis yaitu responden perempuan dengan jumlah 28 orang $(66,7 \%)$. Hasil uji Chi-Square menghasilkan $p$-value $=$ 0,024 yaitu ada hubungan jenis kelamin dan pencarian pengobatan malaria.

Perilaku seseorang dibentuk oleh faktor pengetahuan dan sikap. Kedua faktor tersebut juga dipengaruhi oleh jenis kelamin. Secara teori, perempuan lebih peduli dalam menjaga kesehatannya. Sedangkan laki-laki lebih permisif pada hal-hal yang tidak baik bagi kesehatan . Hal ini sesuai fakta bahwa angka 
kesakitan kelompok perempuan di indonesia lebih kecil daripada kelompok laki-laki. Perilaku menjaga kesehatan tersebut juga bisa diterapkan pada perilaku pencarian pengobatan malaria berdasarkan jenis kelamin seseorang (Armaidi, 2014).

Hasil penelitian ini sesuai dengan penelitian Ajami (2016) di Minahasa yang menyatakan bahwa ada hubungan antara jenis kelamin dengan perilaku pencarian pengobatan malaria.

Pencarian pengobatan medis kelompok perempuan dipengaruhi oleh dua faktor utama. Pertama, tingkat kepedulian terhadap kesehatan yang lebih baik. Kedua, kondisi fisik yang lebih rentan, seperti kelompok ibu hamil, sehingga membutuhkan metode pengobatan yang lebih terbukti efektif.

\section{Pendidikan}

Hasil penelitian menunjukkan bahwa sebagian besar responden yang mencari pengobatan tradisional adalah responden berpendidikan dasar yaitu 14 orang $(50,0 \%)$. Sedangkan sebagian besar responden pengobatan medis adalah responden berpendidikan tinggi berjumlah 16 orang $(38,0 \%)$. Hasil uji Chi-Square adalah $p$-value $=0,110$ bahwa tidak ada hubungan pendidikan dan pencarian pengobatan malaria.

Pendidikan mempengaruhi tingkat pengetahuan dan sikap seseorang. Pengetahuan dan sikap kemudian membentuk perilaku. Oleh karena itu, semakin tinggi pendidikan maka semakin baik pula pengetahuan sikap yang ia miliki. Pengetahuan dan sikap yang baik ini akan membentuk perilaku sehat, misalnya mencari pengobatan medis dengan biaya besar untuk menyembuhkan penyakit malaria yang sedang dialami (Ipa, 2015).

Hasil penelitian ini sesuai dengan penelitian Suharno (2015) yang menyebutkan menyatakan bahwa ada hubungan antara pendidikan dengan pencarian pengobatan malaria. Penderita malaria dengan pendidikan rendah akan lebih memilih pengobatan tradisional. Penderita malaria dengan pendidikan tinggi akan menggunakan pengobatan medis. Hal ini terjadi karena pada umumnya seseorang berpendidikan tinggi memiliki tingkat ekonomi yang lebih baik sehingga bisa memberinya keleluasaan menggunakan pengobatan medis yang tentunya membutuhkan biaya yang lebih besar. 
Tabel 1. Hubungan Antara Umur Dengan Pencarian Pengobatan Malaria Di Wilayah Kerja Pus kesmas Kaligesing Kabupaten Purworejo

\begin{tabular}{|c|c|c|c|c|c|c|c|}
\hline \multirow{3}{*}{ Umur } & \multicolumn{6}{|c|}{ Pencarian Pengobatan } & \multirow[t]{2}{*}{$p$ value } \\
\hline & \multicolumn{2}{|c|}{ Tradisional } & \multicolumn{2}{|c|}{ Medis } & \multirow[b]{2}{*}{ Total } & \multirow[b]{2}{*}{$\%$} & \\
\hline & $\mathbf{F}$ & $\%$ & $\bar{F}$ & $\%$ & & & \\
\hline Remaja & 9 & 52,9 & 8 & 47,1 & 17 & 100 & 0,300 \\
\hline Dewasa & 11 & 31,4 & 24 & 68,6 & 35 & 100 & \\
\hline Lansia & 8 & 44,4 & 10 & 55,6 & 18 & 100 & \\
\hline \multicolumn{7}{|c|}{$O R=2,40$} & \\
\hline
\end{tabular}

Tabel 2. Hubungan Antara Jenis Kelamin Dengan Pencarian Pengobatan Malaria Di Wilayah Kerja Puskesmas Kaligesing Kabupaten Purworejo

\begin{tabular}{|c|c|c|c|c|c|c|c|}
\hline \multirow{3}{*}{ Pekerjaan } & \multicolumn{4}{|c|}{ Pencarian Pengobatan } & & & \multirow[t]{2}{*}{$p$ value } \\
\hline & \multicolumn{2}{|c|}{ Tradisional } & \multicolumn{2}{|c|}{ Medis } & & & \\
\hline & $\mathbf{F}$ & $\%$ & $\mathbf{f}$ & $\%$ & Total & $\%$ & \\
\hline Laki-laki & 17 & 54,8 & 14 & 45,2 & 31 & 100 & 0,024 \\
\hline Perempuan & 11 & 28,2 & 28 & 71,8 & 39 & 100 & \\
\hline
\end{tabular}

Tabel 3. Hubungan Antara Pendidikan Dengan Pencarian Pengobatan Malaria Di Wilayah Kerja Puskes mas Kaligesing Kabupaten Purworejo

\begin{tabular}{lccccccc} 
& \multicolumn{3}{c}{ Pencarian Pengobatan } & p value \\
\cline { 2 - 8 } Pendidikan & \multicolumn{2}{c}{ Tradisional } & \multicolumn{2}{c}{ Medis } & \multicolumn{2}{c}{ Total } & \\
\cline { 2 - 8 } & $\mathbf{F}$ & $\boldsymbol{\%}$ & $\mathbf{f}$ & $\mathbf{\%}$ & Total & \% & \\
\hline Tinggi & 6 & 27,3 & 16 & 72,7 & 70 & 100 & 0,110 \\
Menengah & 8 & 34,8 & 15 & 65,2 & 42 & 100 & \\
Dasar & 14 & 56,0 & 11 & 44,0 & 28 & 100 & \\
\hline \multicolumn{8}{c}{$O R=3,091$} \\
\hline
\end{tabular}

Tabel 4. Hubungan Antara Pekerjaan Dengan Pencarian Pengobatan Malaria

Di Wilayah Kerja Puskes mas Kaligesing Kabupaten Purworejo

\begin{tabular}{|c|c|c|c|c|c|c|c|}
\hline \multirow{3}{*}{ Pekerjaan } & \multicolumn{4}{|c|}{ Pencarian Pengobatan } & & & \multirow[t]{2}{*}{$p$ value } \\
\hline & \multicolumn{2}{|c|}{ Tradisional } & \multicolumn{2}{|c|}{ Medis } & & & \\
\hline & $\mathbf{F}$ & $\%$ & $\mathbf{f}$ & $\%$ & Total & $\%$ & \\
\hline Bekerja & 12 & 30,8 & 27 & 69,2 & 39 & 100 & 0,077 \\
\hline $\begin{array}{l}\text { Tidak } \\
\text { Bekerja }\end{array}$ & 16 & 51,6 & 15 & 48,4 & 31 & 100 & \\
\hline
\end{tabular}

$$
O R=2,400
$$

Tabel 5. Hubungan Antara Pendapatan Dengan Pencarian Pengobatan Malaria Di Wilayah Kerja Puskes mas Kaligesing Kabupaten Purworejo 


\begin{tabular}{lccccccc}
\hline & \multicolumn{9}{c}{ Pencarian Pengobatan } & & p value \\
\cline { 2 - 8 } Pendapatan & Tradisional & \multicolumn{3}{c}{ Medis } & & & \\
\cline { 2 - 8 } & F & \% & f & \% & Total & \% & \\
\hline Tinggi & 15 & 51.7 & 14 & 48.3 & 29 & 100 & 0,092 \\
Rendah & 13 & 31.7 & 28 & 68.3 & 41 & 100 & \\
\hline \multicolumn{7}{c}{$O R=2,308$} \\
\hline
\end{tabular}

Tabel 6. Hubungan Antara Kepercayaan Dengan Pencarian Pengobatan Malaria Di Wilayah Kerja Puskes mas Kaligesing Kabupaten Purworejo

\begin{tabular}{|c|c|c|c|c|c|c|c|}
\hline \multirow{3}{*}{ Kepercayaan } & \multicolumn{4}{|c|}{ Pencarian Pengobatan } & & & \multirow[t]{2}{*}{$p$ value } \\
\hline & \multicolumn{2}{|c|}{ Tradisional } & \multicolumn{2}{|c|}{ Medis } & & & \\
\hline & $\mathbf{F}$ & $\%$ & $\mathbf{f}$ & $\%$ & Total & $\%$ & \\
\hline Positif & 8 & 23,5 & 26 & 76,5 & 34 & 100 & 0,006 \\
\hline Negatif & 20 & 55,6 & 16 & 44,4 & 36 & 100 & \\
\hline
\end{tabular}

Tabel 7. Hubungan Antara Pengetahuan Dengan Pencarian Pengobatan Malaria Di Wilayah Kerja Puskes mas Kaligesing Kabupaten Purworejo

\begin{tabular}{|c|c|c|c|c|c|c|c|}
\hline \multirow{3}{*}{ Pengetahuan } & \multicolumn{4}{|c|}{ Pencarian Pengobatan } & \multirow[b]{3}{*}{ Total } & \multirow[b]{3}{*}{$\%$} & \multirow[t]{3}{*}{$p$ value } \\
\hline & \multicolumn{2}{|c|}{ Tradisional } & \multicolumn{2}{|c|}{ Medis } & & & \\
\hline & $\mathbf{F}$ & $\%$ & $\mathbf{f}$ & $\%$ & & & \\
\hline Baik & 11 & 25,6 & 32 & 74,4 & 43 & 100 & 0,002 \\
\hline Kurang Baik & 17 & 63,0 & 10 & 37,0 & 27 & 100 & \\
\hline
\end{tabular}

Tabel 8. Hubungan Antara Kerentanan Dengan Pencarian Pengobatan Malaria Di Wilayah Kerja Puskes mas Kaligesing Kabupaten Purworejo

\begin{tabular}{lcccccccc}
\hline & \multicolumn{9}{c}{ Pencarian Pengobatan } & & p value \\
\cline { 2 - 8 } Kerentanan & \multicolumn{2}{c}{ Tradisional } & \multicolumn{3}{c}{ Medis } & & & \\
\cline { 2 - 8 } & F & \% & f & \% & Total & \% & \\
\hline Rentan & 13 & 33,3 & 26 & 66,7 & 39 & 100 & 0,202 \\
Tidak rentan & 15 & 48,4 & 16 & 51,6 & 31 & 100 & \\
\hline \multicolumn{7}{c}{ OR $=\mathbf{0 , 5 3 3}$} \\
\hline
\end{tabular}

Tabel 9. Hubungan Antara Keparahan Dengan Pencarian Pengobatan Malaria Di Wilayah Kerja Puskes mas Kaligesing Kabupaten Purworejo 


\begin{tabular}{|c|c|c|c|c|c|c|c|}
\hline \multirow{3}{*}{ Keparahan } & \multicolumn{4}{|c|}{ Pencarian Pengobatan } & & & \multirow[t]{2}{*}{$p$ value } \\
\hline & \multicolumn{2}{|c|}{ Tradisional } & \multicolumn{2}{|c|}{ Medis } & & & \\
\hline & $\mathbf{F}$ & $\%$ & $\mathbf{f}$ & $\%$ & Total & $\%$ & \\
\hline Ada & 12 & 27,9 & 31 & 72,1 & 43 & 100 & 0,009 \\
\hline Tidak ada & 16 & 59,3 & 11 & 40,7 & 27 & 100 & \\
\hline \multicolumn{7}{|c|}{$O R=0,266$} & \\
\hline
\end{tabular}

Tabel 10. Hubungan Antara Manfaat Dengan Pencarian Pengobatan Malaria Di Wilayah Kerja Puskes mas Kaligesing Kabupaten Purworejo

\begin{tabular}{lccccccc}
\hline & \multicolumn{9}{c}{ Pencarian Pengobatan } & & p value \\
\cline { 2 - 8 } Manfaat Yang & \multicolumn{2}{c}{ Tradisional } & \multicolumn{3}{c}{ Medis } & & \\
\cline { 2 - 8 } Dirasakan & F & \% & f & \% & Total & \% & \\
\hline Ada & 18 & 34,0 & 35 & 66,0 & 53 & 100 & 0,069 \\
Tidak ada & 10 & 58,8 & 7 & 41,2 & 17 & 100 & \\
\hline \multicolumn{7}{c}{$\boldsymbol{O R}=\mathbf{2 , 7 7 8}$} \\
\hline
\end{tabular}

Tabel 11. Hubungan Antara Hambatan Dengan Pencarian Pengobatan Malaria Di Wilayah Kerja Puskesmas Kaligesing Kabupaten Purworejo

\begin{tabular}{|c|c|c|c|c|c|c|c|}
\hline \multirow{3}{*}{$\begin{array}{l}\text { Hambatan } \\
\text { Yang Dirasakan }\end{array}$} & \multicolumn{4}{|c|}{ Pencarian Pengobatan } & & & \multirow[t]{3}{*}{ p value } \\
\hline & \multicolumn{2}{|c|}{ Tradisional } & \multicolumn{2}{|c|}{ Medis } & \multirow[b]{2}{*}{ Total } & \multirow[b]{2}{*}{$\%$} & \\
\hline & $\mathbf{F}$ & $\%$ & $\mathbf{f}$ & $\%$ & & & \\
\hline Tidak ada & 21 & 47,7 & 23 & 52,3 & 44 & 100 & 0,069 \\
\hline Ada & 7 & 26,9 & 19 & 73,1 & 26 & 100 & \\
\hline
\end{tabular}

\section{PEMBAHASAN}

\section{Pekerjaan}

Hasil penelitian menunjukkan bahwa sebagian besar responden yang mencari pengobatan tradisional adalah responden yang tidak bekerja yaitu berjumlah 15 orang $(57,1 \%)$. Sedangkan sebagian besar responden yang mencari pengobatan medis adalah responden yang bekerja yaitu berjumlah 27 orang (64,2\%). Hasil uji Chi-Square menghasilkan p-value = 0,077 yang berarti tidak ada perbedaan hubungan antara status pekerjaan responden penelitian dengan pencarian pengobatan malaria. Pekerjaan adalah salah satu faktor sosioekonomi yang 
bisa membentuk pola perilaku pekerjaan dengan pencarian kesehatan seseorang. Seseorang yang pengobatan malaria menunjukkan bekerja akan memiliki lingkungan dan bahwa adanya kesamaan pencarian interaksi sosial yang lebih luas pengobatan malaria oleh responden sehingga lebih banyak terpapar yang bekerja sebagai petani. Hal ini berbagai informasi yang akan sesuai dengan status sosiodemografi meningkatkan pengetahuannya. Pada masyarakat Purworejo yang bekerja akhirnya, pengetahuan tersebut akan sebagai petani dan secara topografis membentuk sikap dan perilaku. yang merupakan wilayah beriklim Semakin banyak informasi yang tropis basah dengan suhu antara $19^{\circ} \mathrm{C}$ diperoleh maka akan semakin baik pula $28^{\circ} \mathrm{C}$ dan kelembaban udara antara 70 pengetahuan dan sikap yang akan \%-90\%.

terbentuk yang selanjutnya akan Pendapatan

membentuk perilaku (Edward, 2014).

Pencarian pengobatan malaria adalah contoh nyata bagaimana seseorang mengolah informasi yang dia peroleh Informasi tersebut tentunya juga bersumber dari lingkungan dan interkasi sosial dalam pekerjaannya. Hasil penelitian ini sesuai dengan penelitian Pujiyanti (2008) di Kebumen yang menyebutkan adanya hubungan antara pekerjaan dengan pencarian pengobatan malaria. Salah satu pekerjaan yang paling berisiko terkena malaria adalah petani. Hal ini penting mengingat sebagian besar responden penelitian tinggal di daerah pegunungan dan bekerja sebagai petani. Tidak adanya hubungan antara

Hasil penelitian menunjukkan bahwa sebagian besar responden yang mencari pengobatan tradisional adalah responden berpendapatan rendah yang berjumlah 15 orang $(53,5 \%)$. Sedangkan sebagian besar responden yang mencari pengobatan medis adalah responden berpendapatan tinggi berjumlah 28 orang $(66,7 \%)$. Hasil uji Chi-Square menghasilkan p-value = 0,092 yang berarti bahwa tidak ada hubungan antara pendapatan dengan pencarian pengobatan malaria.

Pendapatan adalah salah satu faktor penting yang mempengaruhi perilaku kesehatan seseorang. Semakin tinggi pendapatan seseorang maka kemungkinan terbentuknya perilaku 
yang sehat juga semakin besar. Hal ini terjadi karena pada umumnya seseorang dengan pendapatan tinggi juga memiliki kesadaran, pengetahuan dan sikap yang lebih baik untuk menjaga kesehatannya. Sebagai contoh, seseorang berpendapatan tinggi cenderung mencari pengobatan medis yang lebih terbukti dan terpercaya.

Hasil penelitian ini sesuai dengan penelitian Ipa (2015) yang menyatakan bahwa kemungkinan seseorang yang berpendapatan tinggi akan mencari pengobatan medis 7,42 kali lebih besar daripada berpendapatan rendah. Hal tersebut terjadi karena dua faktor. Pertama, adanya kemampuan untuk membayar biaya pengobatan. Kedua, persepsi bahwa manfaat pengobatan medis lebih besar daripada pengobatan tradisional.

\section{Kepercayaan}

Hasil penelitian menunjukkan bahwa sebagian besar responden yang mencari pengobatan tradisional adalah responden yang memiliki kepercayaan negatif dengan jumlah 20 orang $(71,4 \%)$. Sebagian besar responden yang mencari pengobatan medis adalah responden yang memiliki kepercayaan positif dengan jumlah 26 orang
(92,8\%). Hasil uji Chi-Square menghasilkan $p$-value $=0,006$ yang berarti ada hubungan kepercayaan dengan pencarian pengobatan malaria. Kepercayaan adalah faktor sosiobudaya yang juga bisa membentuk perilaku. Kepercayaan seseorang dibentuk oleh berbagai faktor, misalnya referensi dari orang terdekat dan pengalaman. Kepercayaan yang tidak didukung oleh pengetahuan yang baik akan membentuk perilaku yang negatif, begitu pula sebaliknya. Pencarian pengobatan tradisional untuk menyembuhkan malaria yang sedang dialami merepresentasikan tingginya kepercayaan budaya seseorang pada metode pengobatan malaria.

Hasil ini sesuai dengan penelitian Armaidi (2014) yang menyatakan bahwa penderita malaria dengan kepercayaan negatif cenderung 3,45 kali lebih besar untuk mencari pengobatan tradisional. Terdapat tiga alasan mereka mencari pengobatan tradisional, yaitu karena efek samping lebih kecil $(35,7 \%)$, lebih cepat sembuh $(26,6 \%)$ dan harganya relatif lebih murah $(20,0 \%)$. Hal ini tentunya juga dibentuk oleh status sosialekonomi.

\section{Pengetahuan}


Hasil penelitian menunjukkan bahwa sebagian besar responden yang mencari pengobatan tradisional adalah responden berpengetahuan kurang baik yang berjumlah 17 orang $(60,7 \%)$. Sedangkan sebagian besar responden yang mencari pengobatan medis adalah responden yang berpengetahuan baik berjumlah 32 orang $(76,1 \%)$. Hasil uji Chi-Square menghasilkan $p$-value = 0,002. Hal ini berarti bahwa secara statistik ada hubungan antara faktor pengetahuan responden penelitian dengan pencarian pengobatan malaria.

Berbagai teori menyebutkan bahwa pengetahuan sebagai faktor utama pembentuk perilaku seseorang. Semakin baik pengetahuan seseorang maka kemungkinan terbentuknya perilaku yang sehat juga semakin besar. Pengetahuan sendiri dibentuk oleh berbagai hal baik dari dalam atau luar (Priyoto, 2014). Hasil penelitian ini sesuai dengan penelitian Musthofa (2012) yang menjelaskan bahwa seseorang berpengetahuan baik akan mencari pengobatan medis 2,13 kali lebih besar dari berpengetahuan kurang baik. Faktor utama yang mendasari tersebut adalah adanya pengetahuan untuk mempertimbangkan faktor manfaat yang dirasakan. Harga pengobatan tradisional umumnya lebih murah namun hasilnya kurang efektif dan adanya risiko kekambuhan berulang. Sedangkan harga pengobatan medis biasanya lebih mahal namun efektivitas pengoabatan lebih aman dan efektif.

\section{Kerentanan yang Dirasakan}

Hasil penelitian menunjukkan bahwa sebagian besar responden yang mencari pengobatan tradisional adalah responden yang merasa tidak rentan yang berjumlah 15 orang $(53,6 \%)$. Sedangkan sebagian besar responden yang mencari pengobatan medis adalah responden yang merasa rentan yang berjumlah 26 orang $(92,8 \%)$. Hasil uji Chi-Square menghasilkan $p$-value $=$ 0,202 yang berarti bahwa tidak ada hubungan kerentanan dirasakan dengan pencarian pengobatan malaria.

Hasil penelitian ini sesuai dengan penelitian Ipa (2015) yang menyatakan bahwa seseorang yang merasa rentan malaria kemungkinan 2,2 kali lebih besar untuk mencari pengobatan medis. Penderita malaria yang menggunakan pengobatan tradisional umumnya tidak terlalu merasa rentan. Hal ini 
menyebabkan mereka percaya bahwa pengobatan tradisional sudah cukup efektif untuk menyembuhkan malaria.

Kerentanan yang dirasakan adalah penilaian seseorang tentang seberapa mudah dirinya mengalami suatu penyakit tertentu. Faktor ini dibentuk oleh frekuensi terjadinya suatu penyakit tertentu pada seseorang. Semakin sering seseorang mengalami penyakit tertentu maka semakin dirinya merasa rentan pada penyakit tersebut. Semakin rentan seseorang maka upaya dia akan memilih pengobatan yang lebih serius untuk menyembuhkan penyakit tersebut untuk sembuh dari kerentanan dan mencegah keparahan.

\section{Keparahan yang Dirasakan}

Hasil penelitian menunjukkan bahwa sebagian besar responden yang mencari pengobatan tradisional merasa malaria yang dialami tidak parah yang berjumlah 16 orang $(57,1 \%)$. Sebagian besar responden pengobatan medis adalah responden yang merasa malaria yang dialami parah yang berjumlah 31 orang $(73,8 \%)$. Hasil uji Chi-Square menghasilkan $p$-value $=0,009$ yang berarti ada hubungan antara keparahan yang dirasakan dengan pencarian pengobatan malaria.
Hasil penelitian ini sesuai dengan penelitian Nizar (2013) yang menyatakan bahwa seseorang yang merasakan keparahan malaria kemungkinan 6,10 kali lebih besar untuk mencari pengobatan medis. Penderita malaria yang menggunakan pengobatan tradisional umumnya baru pertama kali sakit malaria atau terbiasa menggunakan pengobatan tradisional. Di sisi lain, penderita yang merasa keparahan memilih pengobatan medis. Keparahan yang dirasakan adalah penilaian seseorang tentang seberapa serius suatu penyakit tertentu yang dia alami. Faktor ini dipengaruhi oleh frekuensi dan lama waktu sembuh suatu penyakit tertentu pada seseorang. Semakin sering dan lama waktu sembuh suatu penyakit yang dialami maka seseorang akan merasa semakin merasakan keparahan penyakit tersebut. Pada tahap ini, seseorang umumnya akan mencari pengobatan medis daripada pengobatan tradisional atau alternatif.

\section{Manfaat yang Dirasakan}

Hasil penelitian menunjukkan bahwa sebagian besar responden yang mencari pengobatan tradisional adalah responden yang merasakan manfaat 
pengobatan tradisional yang berjumlah 18 orang $(64,2 \%)$. Sebagian besar responden pengobatan medis adalah responden yang merasakan manfaat pengobatan medis yang berjumlah 35 orang $(83,5 \%)$. Hasil uji Chi-Square menghasilkan $p$-value $=0,069$ yang berarti bahwa tidak ada hubungan antara manfaat yang dirasakan dengan pencarian pengobatan malaria.

Hasil penelitian ini sesuai dengan penelitian Farouk (2016) yang menyatakan seseorang yang pernah merasakan manfaat pengobatan malaria tertentu kemungkinan 3,93 kali lebih besar untuk tetap memilih pengobatan tersebut. Sedangkan kemungkinan seseorang pertama kali mengalami malaria akan memilih suatu metode pengobatan yaitu 2,18 kali lebih besar jika dia memperoleh informasi dari orang yang dia percaya. Oleh karena itu, informasi juga sangat berperan.

Manfaat yang dirasakan adalah penilaian seseorang tentang seberapa baik perubahan yang dia alami setelah berperilaku tertentu. Dalam aspek pencarian pengobatan, faktor ini berarti penilaian seseorang pada pengobatan yang telah dia lakukan berdasarkan tingkat kesembuhannya. Semakin cepat waktu sembuh penyakit yang dia alami dan tidak kambuh, maka dia akan merasa semakin merasakan manfaat pengobatan tersebut.

\section{Hambatan yang Dirasakan}

Hasil penelitian menunjukkan bahwa sebagian besar responden yang mencari pengobatan tradisional adalah responden yang tidak merasahambatan pengobatan tradisional yang berjumlah 21 orang $(75,0 \%)$. Sebagian besar responden pengobatan medis adalah responden yang tidak merasa hambatan pengobatan medis yang berjumlah 23 orang $(54,7 \%)$. Hasil uji Chi-Square menghasilkan p-value sebesar 0,086 yang berarti tidak ada hubungan antara hambatan yang dirasakan dengan pencarian pengobatan malaria.

Hasil penelitian ini sesuai dengan penelitian Pujiyanti (2008) yang menyatakan bahwa seseorang yang tidak merasakan hambatan suatu pengobatan malaria kemungkinan 8,80 kali lebih besar untuk memilih pengobatan itu. Pengobatan tradisional biasanya berjarak dekat dan berharga murah. Hal inilah yang menstimulasi seseorang untuk memilih pengobatan tradisional. Sebaliknya, pengobatan 
medis umumnya berjarak lebih jauh, dan berharga lebih mahal.

Hambatan yang dirasakan adalah penilaian seseorang tentang seberapa sulit untuk berperilaku tertentu. Dalam aspek pencarian pengobatan, faktor ini berarti penilaian seseorang terhadap suatu metode pengobatan yang telah dia lakukan berdasarkan tingkat kesulitan untuk berobat di pengobatan tersebut. Semakin jauh, mahal dan rumit suatu metode pengobatan, maka dia akan merasa semakin merasakan hambatan pengobatan tersebut.

Faktor Yang Berpengaruh Terhadap Pencarian Pengobatan Malaria

Hasil penelitian menunjukkan bahwa terdapat empat variabel yang menjadi kandidat dalam analisis multivariat. Keempat variabel tersebut adalah jenis kelamin $(p$-value $=0,024)$, kepercayaan $(p$-value $=0,006)$, pengetahuan $(p$ value $=0,002)$ dan keparahan yang dirasakan $(p$-value $=0,009)$. Setelah diuji dengan regresi logistik, terdapat dua variabel yang secara bersama-sama berpengaruh terhadap pencarian pengobatan malaria. Kedua variabel tersebut adalah pengetahuan dan keparahan yang dirasakan. Sedangkan variabel yang paling berpengaruh terhadap pencarian pengobatan malaria adalah keparahan yang dirasakan dengan nilai OR yaitu 12,627 (CI 95\% :2,567-62,120).

Hasil tersebut berarti bahwa responden penelitian yang merasa malaria yang dialami sudah parah kemungkinan mencari pengobatan medis sebesar 12,567 kali lebih besar dibandingkan responden yang merasa malaria yang dialami tidak parah. Penderita malaria yang merasakan keparahan tentunya ingin segera sembuh dari penyakitnya. Selain itu, saat merasakan keparahan penyakitnya, seorang penderita malaria cenderung mengabaikan hambatan yang mungkin dirasakan, misalnya jarak, biaya dan proses. Kualitas pengobatan medis yang lebih terbukti dan terpercaya dalam menyembuhkan berbagai penyakit menjadi pilihan utama penderita tersebut. (Armaidi, 2014).

Hal ini terkait keterbatasan pengobatan tradisional dalam menangani penderita dalam kondisi yang sudah parah. Keterbatasan tersebut bisa berupa kualitas tenaga pengobat atau sarana untuk mengobati penderita tersebut. Penderita malaria yang menggunakan 
pengobatan tradisional umumnya baru pertama kali mengalami malaria atau sudah terbiasa untuk menggunakan pengobatan tradisional. Di sisi lain, penderita yang merasa malaria yang dia derita sudah parah akan memilih pengobatan medis yang lebih efektif (Triratnawati, 2014).

\section{SIMPULAN}

1. Sebagian besar responden yang mencari pengobatan tradisional adalah responden berjenis kelamin laki-laki, berumur remaja dan lansia, berpendidikan dasar, tidak bekerja dan berpendapatan rendah. Selain itu, mereka berkepercayaan negatif, berpengetahuan kurang baik, merasakan keparahan dan kerentanan, tidak merasakan manfaat dan hambatan dalam mencari pengobatan tradisional.

2. Sebagian besar responden yang mencari pengobatan medis adalah responden yang berumur dewasa, berjenis kelamin perempuan, berpendidikan tinggi, bekerja dan berpendapatan tinggi. Selain itu, mereka juga berkepercayaan positif, berpengetahuan baik, tidak merasakan kerentanan, manfaat dan hambatan namun merasakan keparahan penyakit malaria.

3. Faktor yang berhubungan dengan pencarian pengobatan malaria antara lain adalah jenis kelamin ( $p$-value $=$ $0,024)$, kepercayaan (p-value $=$ 0,006), pengetahuan ( -value = 0,002) dan keparahan yang dirasakan $(p$-value $=0,019)$. Faktor yang paling berpengaruh adalah keparahan yang dirasakan dengan nilai odds ratio $(\mathrm{OR})$ atau $\operatorname{Exp}(\mathrm{B})=$ 12,657. Hal ini berarti bahwa responden yang merasa malaria yang dialami sudah parah kemungkinan mencari pengobatan medis 12,567 kali lebih besar.

\section{SARAN}

1. Bagi Institusi Kesehatan, diharapkan Dinas Kesehatan merencakan dan melaksanakan program KIE tentang malaria, khususnya tentang upaya pengobatan malaria pada masyarakat yang diawali dengan analisis khalayak. Selain itu, juga diharapkan mengoptimalkan peran tenaga kesehatan, khususnya bidan desa, dan tokoh masyarakat, dalam upaya program KIE dan pengobatan malaria di Kecamatan Kaligesing Kabupaten Purworejo. 
2. Bagi Masyarakat

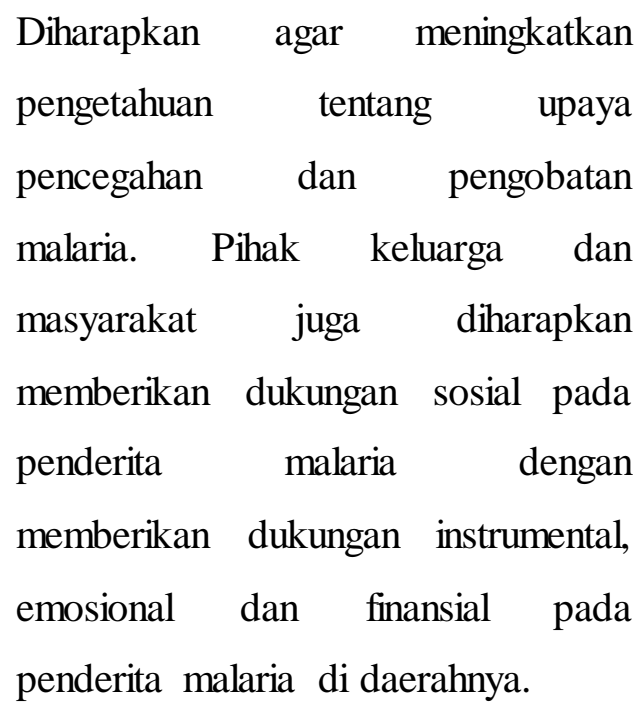

\section{DAFTAR PUSTAKA}

World Health Organization.2017. World Malaria Report 2017. Geneva.

Kementerian Kesehatan Republik Indonesia. 2014. Pengendalian Penyakit Bersumber Binatang tentang Pedoman Manajemen Malaria. Jakarta.

Ajami WA., Ottay RI., Robot DV. 2016. Hubungan Antara Perilaku Masyarakat Dengan Kejadian Malaria Di Wilayah Kerja Puskesmas Tombatu Kabupaten Minahasa Tenggara. Jurnal Kedokteran Komunitas Tropik.. 4(1) : 65-72

Ipa M., Dhewantara PW. 2015 Variasi Pengobatan Malaria Rumah
Tangga Di Enam Provinsi Endemis Malaria Di Indonesia. Jurnal Aspirator.. 7(1) : 13-22.

Dinas Kesehatan Kabupaten Purworejo. 2015. Profil Kesehatan. Dinas Kesehatan Purworejo Tahun 2015.

Nizar M., Taviv Y., Sembiring TU., Hakim K. 2013, Faktor Yang Mempengaruhi Pembelian Obat Malaria Di Warung. Jurnal Aspirator.. 5(1)9-15.

Suharno. 2015. Pengetahuan Sikap Dan Perilaku Masyarakat Tentang Malaria Di Daerah Endemis Kalimantan Selatan. Jurnal Media Litbangkes. 25(1) : 23-32. Armaidi.2014.Gambaran Obat Tradisional yang Digunakan Penderita Malaria Di Wilayah Puskesmas Simpang IV Sipin Kota Jambi. Jurnal JMJ. 2(2) : 114-126

Farouk HA. 2016. .Analisis Faktor Yang Berhubungan Dengan Kepatuhan Pengobatan Malaria Di Kabupaten Sarolangun Provinsi Jambi. Jurnal Ilmiah Universitas Batanghari Jambi. 16(1) : 1-11

Triratnawati, A. Dominasi Medis Modern Atas Medis Tradisional Suku Sumuri, Teluk Bintuni, Papua Barat. Jurnal Masyarakat, Kebudayan dan Politik. 30 (2) : 174-187. 